Original Research Paper

\title{
Removal of Copper from Aqueous Solution using Tunisian Clay
}

\author{
Boujelben, N., S. Gharab, F. Bouhamed, Z. Elouear and J. Bouzid \\ Laboratory of Water, Energy and Environment, Department of Geology, \\ National Engineering School of Sfax, BP W 3038 Sfax, Tunisia
}

\section{Article history}

Received: 30-01-2015

Revised: $18-04-2015$

Accepted: 05-06-2015

Corresponding author:

Boujelben, N.

Laboratory of Water, Energy and

Environment, department of geology, National Engineering School of Sfax, BP W 3038 Sfax, Tunisia

Email: boujelbenn@yahoo.fr

\begin{abstract}
Natural adsorbents such as clay was used to replace expensive imported synthetic adsorbents. In this study, Scanning Electron Microscopy (SEM), Infrared spectroscopy and X-ray diffraction techniques were used to characterize the used sorbent (clays $\mathrm{C}$ ). Batch experiments were performed to evaluate the effects of contact time, solution $\mathrm{pH}$ and temperature on copper removal onto used sorbent from aqueous solution. Equilibrium data were analyzed using Langmuir and Freundlich isotherm models to calculate isotherm constants. Kinetic studies showed that an equilibrium time of $1 \mathrm{~h}$ was required for the adsorption of $\mathrm{Cu}$ (II) onto Tunisian clay. Equilibrium adsorption is affected by the initial $\mathrm{pH}$ of the solution. The maximum adsorption capacity was obtained at $\mathrm{pH} 5$. Adsorption tests in synthetic wastewater revealed that the adsorption data of this material for copper ions were better fit to the Langmuir isotherm based on correlation coefficients. The influence of temperature on the adsorption process was also evaluated. Results indicated that adsorption of $\mathrm{Cu}(\mathrm{II})$ on the sorbents is endothermic. The thermodynamic parameters $\left(\Delta G^{\circ}, \Delta H^{\circ}\right.$ and $\left.\Delta S^{\circ}\right)$ for $\mathrm{Cu}(\mathrm{II})$ sorption were also determined from the temperature dependence. Results of this study suggest that used Tunisian clay may be a promising adsorbents for environmental remediation.
\end{abstract}

Keywords: Copper, Adsorption, Clay, Isotherms

\section{Introduction}

The potential sources of copper in industrial waste streams include metal cleaning and plating baths, pulp, paper and paperboard mills, wood pulp production, fertilizer industry, etc. (Dean et al., 1972). Excessive intake of copper results in its accumulation in the liver. The chronic copper poisoning is related to hemochromatosis when present in large amounts (Camp, 1964). It is also toxic to fish life even when its content is in low amounts in natural waters (Camp, 1964).

Removal of heavy metals from contaminated aquatic systems is deemed important for the protection of environmental health. Therefore, it is urgent to remove those toxic heavy metals from wastewater. Although heavy metal removal from aqueous solutions can be achieved by conventional methods, including chemical precipitation, oxidation/reduction, electrochemical treatment, evaporative recovery, filtration, ion exchange and membrane technologies, they may be ineffective or cost-expensive, especially when the metal ion concentrations in solution are in the range of $1-100 \mathrm{mg}$ $\mathrm{L}^{-1}$ (Dhakal et al., 2005; Liang et al., 2009). Recently, adsorption technology has become one of the alternative treatments in either laboratory or industrial scale (Kumar and Bandyopadhyay, 2006; Singh et al., 2006). Therefore, adsorption is the most frequently applied technique owing to its advantages, such as variety of adsorbent materials and high efficiency at a relatively lower cost (Mohan and Pittman, 2006). Although activated carbon is one of the most popular adsorbents for removal of metal ions (Schindler et al., 1996; Mohan and Pittman, 2006; Zhang et al., 2007), current investigations tend towards achieving high removal efficiencies with much cheaper materials which are mostly cheap and abundant matter. The development of new and more effective adsorbents, like clay, has become essential, but at the same time it should be of low cost.

Mineral clay can absorb heavy metals via two different mechanisms: (1) Cation exchange at the planar sites, resulting from the interactions between metal ions 
and negative permanent charge (outer-sphere complexes) and (2) innersphere complexes formation through $\mathrm{SiO}$ and $\mathrm{AlO}_{-}$groups at the clay particle edges (Babel and Kurniawan, 2003). Both mechanisms are $\mathrm{pH}$ dependent but the latter is particularly influenced by $\mathrm{pH}$ because in acidic conditions $(\mathrm{pH}<4)$ most silanol and aluminol groups on edges are protonated. For this reason, it is necessary to improve the knowledge of the effect of $\mathrm{pH}$ on the sorption capacity of mineral clay in solid-solution system.

The aim of this work is to study the removal of $\mathrm{Cu}$ (II) from aqueous solution by adsorption on Tunisian clay (C) after physicochemical characterization of the used sorbent.

\section{Materials and Methods}

\section{Sorbent and Adsorbate}

The raw clay used in this study was collected from Cap Bon region In the North East of Tunisia. Clay sample was collected from Jbel Abderrahmen.

Aqueous solutions containing copper ions ( $\mathrm{Cu}$ II) at various concentrations were prepared from copper salts (CuSO4.5H2O). All chemicals used for the treatment of the different sorbents and for adsorption tests were of analytical quality. The various solutions are prepared in distilled water.

\section{Mineral Identification of Adsorbents}

The mineralogical analysis of the raw sample was carried out by X-ray diffraction (Phillips X'Pert diffractometer) on the oriented aggregates; normal $(\mathrm{N})$, was treated with ethylene glycol (T) and heated at $500^{\circ} \mathrm{C}$ for $2 \mathrm{~h}(\mathrm{H})$. The XRD spectrum of oriented aggregates is presented in Fig. 1. The chemical composition was determined by ICP-AES. Loss On Ignition (LOI) was considered as the weight percent difference between sample heated at 100 and $1,000^{\circ} \mathrm{C}$. An IR transmittance spectrum of the mineral clay sample was obtained in the $4,000-500 \mathrm{~cm}^{-1}$ range using a SHIMATZU IR 470 spectrometer.

The used clay specific surface area $\left(\mathrm{m}^{2} / \mathrm{g}\right)$ was determined by the single-point BET adsorption procedure. Standard report of clay and distilled water (with stirring) is dosed by methylene blue, until saturation of clay particles. The end of the test is determined by the persistence of a clear blue halo, indicating the saturation of the clay.

The X-ray diffraction analysis indicated that the raw clay is mainly composed of Kaolinite (51\%), Illite (45\%) and $4 \%$ Smectites (Table 1 ).

The chemical analysis showed that the clay sample was characterized by a rate of $50.59 \% \mathrm{SiO} 2$ (Table 2) the alumina is $17,24 \%$. This verifies the presence of an aluminosilicate material in the studied samples. The percentage of iron oxide is relatively high $(9.97 \%)$ This is typical clays Tunisian (Benzina and Bellagi, 1990).

The loss at high fire is due to the presence of a slightly higher rate of smectite in which are intercalated water molecules, with the presence of $\mathrm{MgO}$ and $\mathrm{CaO}$.

The BET surface area of clay sample was found to be $180.2 \mathrm{~m}^{2} / \mathrm{g}$.

The infrared absorption spectrum (Fig. 2) of clay showed the presence of peaks characteristic of the silica present in the sample. The results confirm those found in the chemical composition of the support.

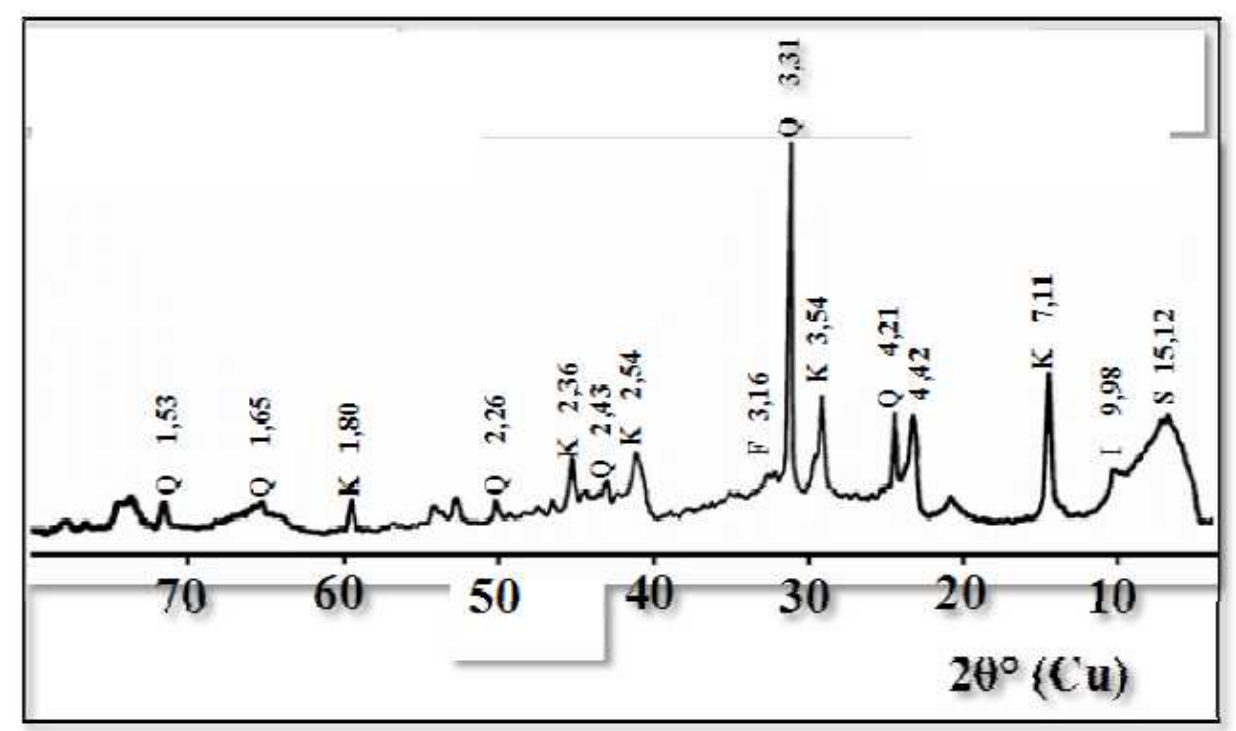

Fig. 1. XRD spectrum of oriented aggregates of clay sample 


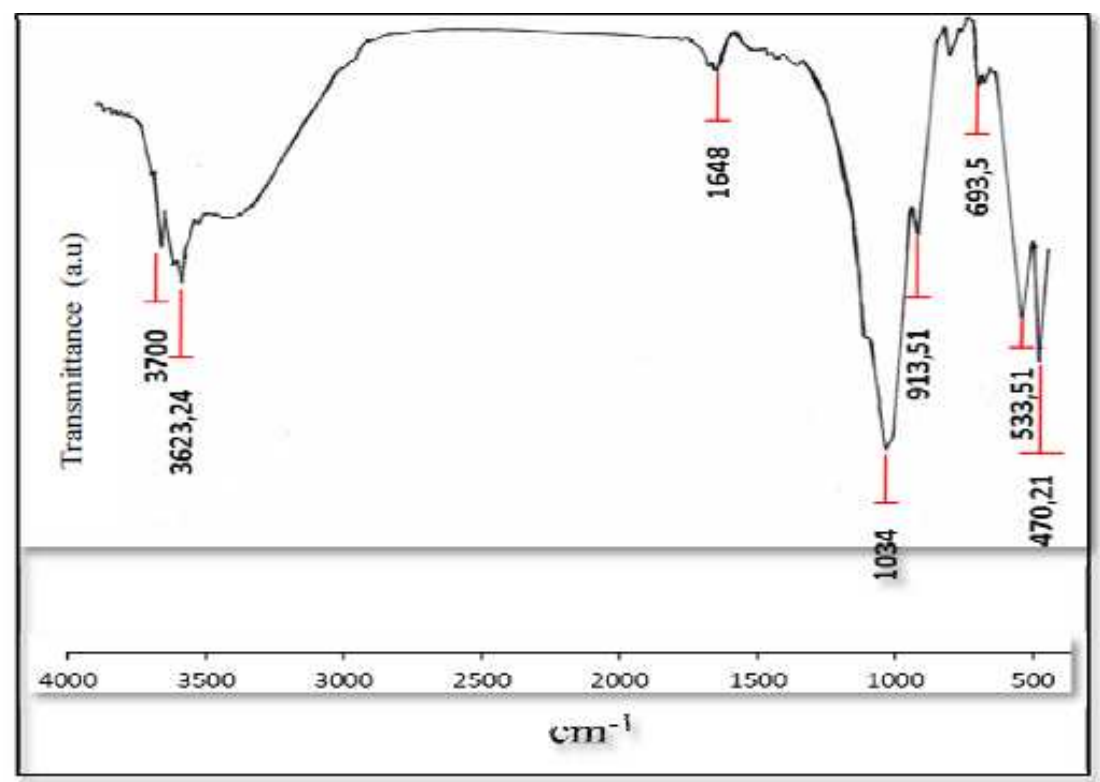

Fig. 2. FT-IR spectra of clay

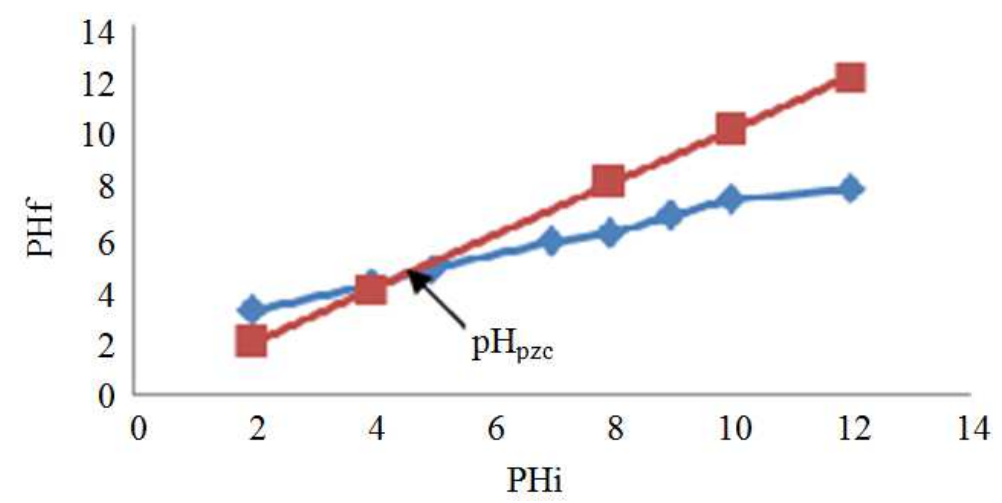

Fig. 3. Point of zero charge of used clay

Table 1. Mineralogical composition of clay

\begin{tabular}{llllllll}
\hline Mineral & Illite $(\mathrm{I})$ & Kaolinite $(\mathrm{K})$ & Smectite $(\mathrm{S})$ & Phyllosilicate $(\mathrm{PH})$ & Calcite $(\mathrm{C})$ & Quartz $(\mathrm{Q})$ & Feldspath $(\mathrm{F})$ \\
\hline $\mathrm{Ab}$ & 45 & 51 & 4 & 76 & 3 & 19 & 2 \\
\hline
\end{tabular}

Table 2. Chemical composition of clay

\begin{tabular}{|c|c|c|c|c|c|c|c|c|c|c|c|c|c|c|c|}
\hline \multirow[b]{2}{*}{ Samples } & \multicolumn{15}{|c|}{ Composition (\%) } \\
\hline & $\mathrm{SiO} 2$ & $\mathrm{Al} 2 \mathrm{O} 3$ & $\mathrm{Fe} 2 \mathrm{O} 3$ & $\mathrm{CaO}$ & $\mathrm{MgO}$ & $\mathrm{Na} 2 \mathrm{O}$ & $\mathrm{K} 2 \mathrm{O}$ & $\mathrm{MnO}$ & $\mathrm{Cr} 2 \mathrm{O} 3$ & $P 205$ & $\mathrm{TiO} 2$ & $P F$ & $\mathrm{~Pb} 2 \mathrm{O} 3$ & $\mathrm{ZnO}$ & $\mathrm{Ni2O} 3$ \\
\hline Clay & 22,38 & 1,53 & - & 0,46 & 3,96 & 1,7 & 10,01 & - & - & - & - & - & 0,017 & 0,045 & 0,029 \\
\hline
\end{tabular}

The powder morphology of sorbents was obtained using a Philips XL 30 Scanning Electron Microscope (SEM). Elemental spectra were obtained using energy dispersive X-ray spectroscopy during SEM observations.

The image obtained is shown in Fig. 3 note the presence of micropores. The crude clay is a porous material whose porosity depends on the geometry, size and distribution of pores. We can see in this figure the clay structure layers of this mineral.

The $\mathrm{pH}$ of zero point of charge (pHzpc) was determined by adding a known amount of adsorbent $(0.1 \mathrm{~g})$ to a series of bottles that contained $50 \mathrm{~mL}$ of deionised water. Before adding the adsorbent, the $\mathrm{pH}$ of the solutions was adjusted to be in the range of 1.0- 
9.0 by the addition of either $0.1 \mathrm{M} \mathrm{HNO3} \mathrm{or} 0.1 \mathrm{M}$ $\mathrm{NaOH}$. These bottles were then rotated for $1 \mathrm{~h}$ in a shaker and $\mathrm{pH}$ values were measured at the end of the test. The $\mathrm{pH}$ of the suspensions is represented as a function of the initial $\mathrm{pH}$ of the solutions. The curve obtained theoretically cross the bisector of axes at the point of zero charge.

According to Fig. 4, it is found that the $\mathrm{pH}_{\mathrm{ZPC}}$ is equal to 5.6 for the adsorbent considered.

For $\mathrm{pHi}$ values acid increased final $\mathrm{pH}$ is faster than for a $\mathrm{pHi}$ alkaline. The variation in the $\mathrm{pHi} \mathrm{pHf}$ is due to the interaction of the support with the solution aqueuse. En acid medium equilibrium occurs from the left to the right, thereby producing the rapid increase pHf (Mohan and Pittman, 2006). The value of pHZPC is dependent on several factors including: The crystalline form, Originally, the conditions of preparation, the presence of impurities ... for this reason it varies of a given type of clay to another.

A pH meter (models pH 540 GLP) equipped with a combined glass electrode SENTIX 41 was used to measure the $\mathrm{pH}$ of the solutions. A preliminary calibration is systematically carried out using suitable buffer solutions. The concentrations of copper ions were measured by an atomic absorption spectrometer (HITACHI Z-6100) by electrothermal atomization mode.

\section{Effect of Various Operating Parameters on Copper (II) Removal}

\section{Effect of Adsorbent Amount}

The influence of the amount of clay adsorbent (0.1-2 $\mathrm{g} / 200 \mathrm{~mL}$ ) on $\mathrm{Cu}$ (II) removal at constant values of initial metal concentration, contact time $(60 \mathrm{~min})$ and temperature $\left(25^{\circ} \mathrm{C}\right)$ is shown in Fig. 5. The results showed that the removal of copper increased rapidly to $80 \%$, until a sorbent dose of $1.5 \mathrm{~g} / 200 \mathrm{~mL}$ and moderately beyond this value. This was an expected result since as the sorbent dose increased, the number of adsorbent sites increased; therefore, these amounts attached more ions to their surfaces (Abollino et al., 2002).

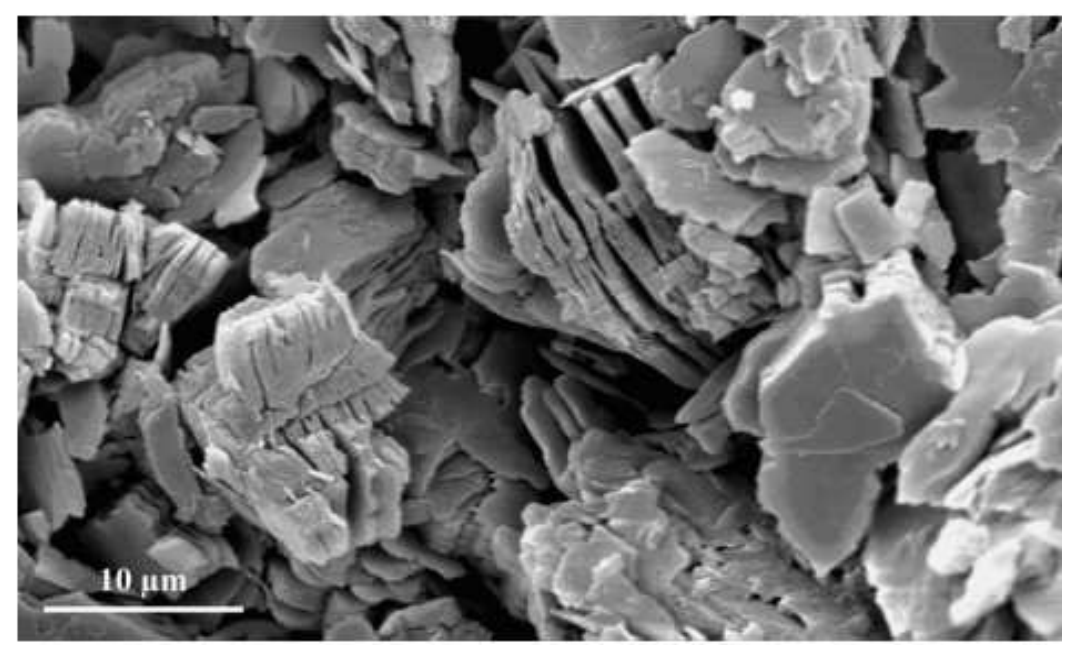

Fig. 4. SEM micrograph of used clay

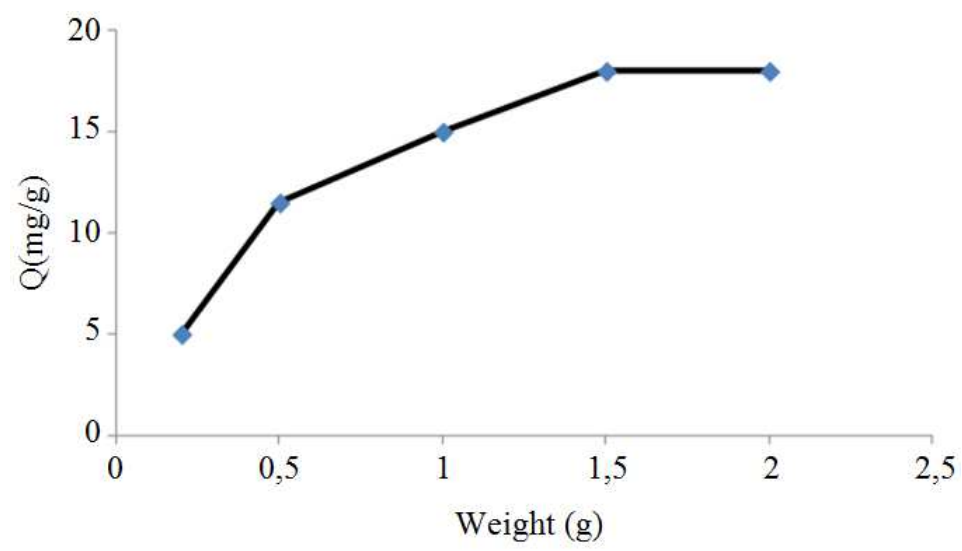

Fig. 5. Effect of adsorbent amount on $\mathrm{Cu}(\mathrm{II})$ adsorption 


\section{Effect of $p H$}

The influence of $\mathrm{pH}$ on the removal of $\mathrm{Cu}$ (II) ions by clay sample was investigated. In the present work, copper adsorption was studied in the $\mathrm{pH}$ range of 2-6 with a constant clay amount of $1.5 \mathrm{~g} / 200 \mathrm{~mL}$ of effluent and a shaking time of $60 \mathrm{~min}$.

The results presented in Fig. 6 reveal that the adsorption of copper increases from 91 to $95.7 \%$ with an increase in solution $\mathrm{pH}$ from 2 to 6 and then decreases rapidly at $\mathrm{pH} \geq 6$. The effect of $\mathrm{pH}$ can be explained in terms of pzc (point of zero charge) of the adsorbent MOM R equal to 5.6 (Shukla et al., 2005). Above 5.6, adsorbent surface is a negatively charged clay; therefore, adsorption percentage progressively increases from 2 to $6 \mathrm{pH}$ by electrostatic attraction.

Below pzc adsorption decreases due to electrostatic repulsion between the positively charged surfaces of adsorbent and cationic metal $\mathrm{Cu}$.

\section{Effect of Shaking Time}

The time-dependent behavior of copper adsorption was studied by varying the contact time between the adsorbate and adsorbent in the range 1-120 $\mathrm{min}$. The clay sample dose was $1.5 \mathrm{~g} / 200 \mathrm{~mL}$ and the solution $\mathrm{pH}$ was fixed at 5.6. The data showed that the adsorption was very fast (Fig. 7). According to the experimental results of several authors (Gupta and Bhattacharyya, 2006; Das and Jana, 2005) on the retention of heavy metals on clay minerals, the adsorption process is fast at the beginning of the reaction due to the adsorption of copper on the surface sites of clay, then it becomes slow due to the diffusion of heavy metals from the surface sites to the interlayer of the solid. Therefore, a $60 \mathrm{~min}$ shaking time was found to be appropriate for maximum adsorption and was used in all subsequent measurements.

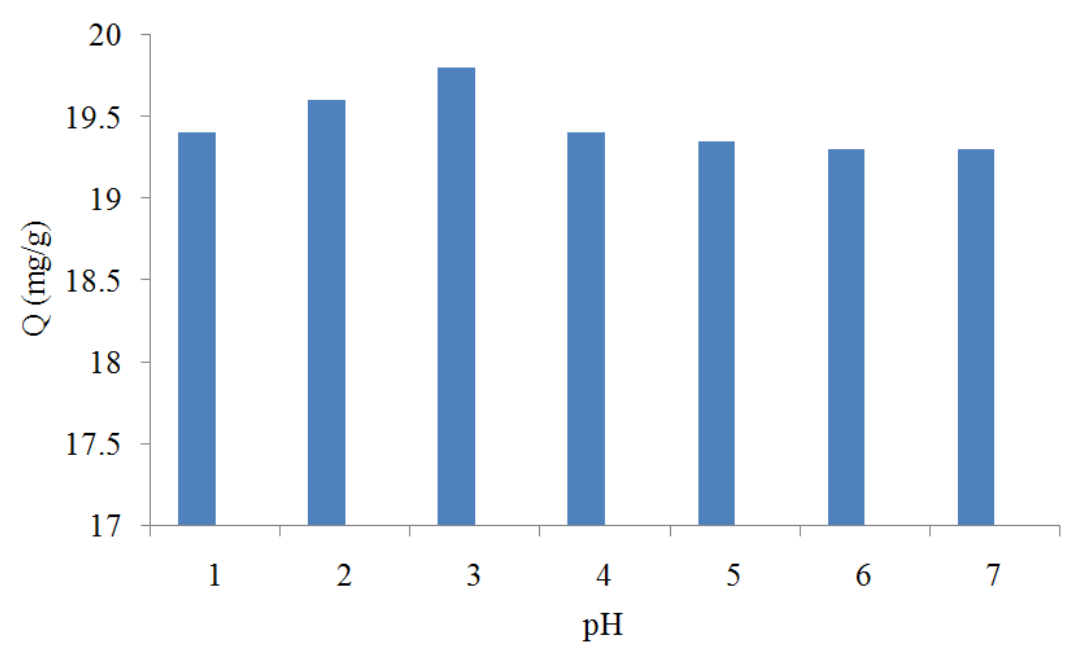

Fig. 6. Effect of $\mathrm{pH}$ on $\mathrm{Cu}(\mathrm{II})$ adsorption

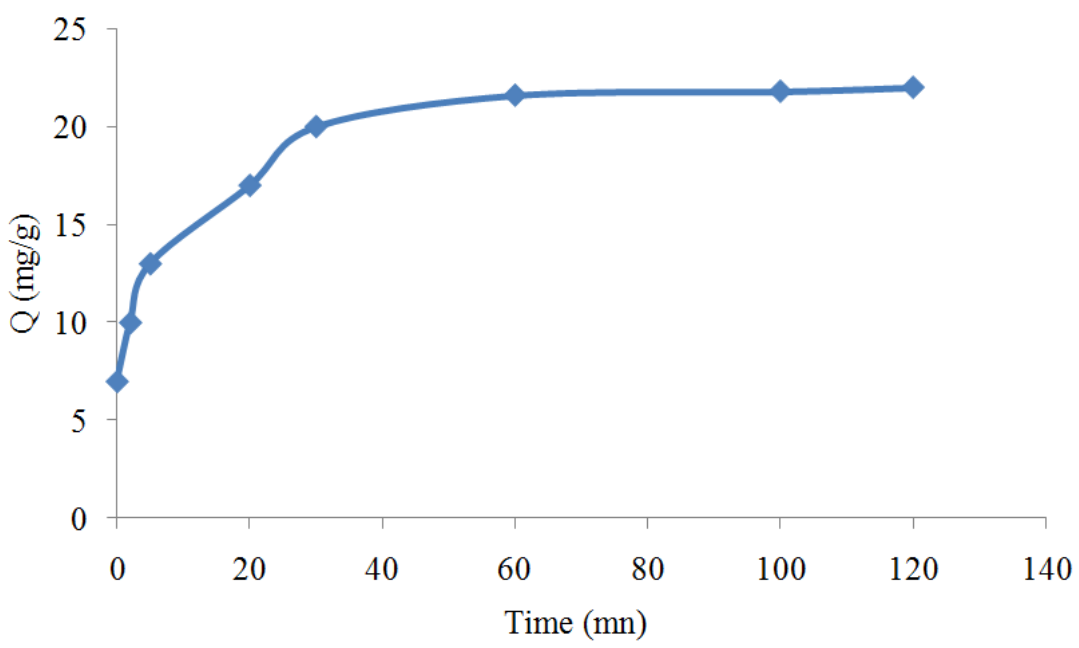

Fig. 7. Effect of shaking time on $\mathrm{Cu}(\mathrm{II})$ adsorption 


\section{Adsorption Isotherm}

Copper ions adsorption isotherms obtained for mineral clay adsorbents are shown in Fig. 8. These isotherms represent the adsorption behavior of $\mathrm{Cu}$ (II) ions on the clay adsorbents as a function of increasing aqueous copper concentration, for a contact time of $60 \mathrm{~min}$.

The Freundlich isotherm model used for copper adsorption (Fig. 9) is the earliest known relationship describing the adsorption equilibrium.

This fairly satisfactory empirical model can be used for non-ideal adsorption and is expressed by the following Equation 1:

$Q=K_{F} C_{e}^{1 / n}$

where, $K f$ and $\mathrm{n}$ are constants related to the adsorption capacity and affinity, respectively. The equation is conveniently used in the linear form by taking the logarithm of both sides (Equation 2):

$$
\log (Q)=\log K F+1 / n \log C e
$$

Table 4 indicates that there is a slight deviation from linearity using the Freundlich isotherm model for describing $\mathrm{C}(\mathrm{II})$ adsorption $\left(\mathrm{R}^{2}\right.$ equal to 0.89 ). Freundlich parameters $(K f$ and $n)$ indicate whether the nature of adsorption is either favorable or unfavorable (Frimmel and Huber, 1996). The intercept is an indicator of adsorption capacity and the slope is an indicator of adsorption intensity. In the adsorption systems, values obtained of $1<\mathrm{n}<10$ imply favorable adsorption. The $\mathrm{Kf}$ values, reported in Table $3 \mathrm{~b}$, can be used to indicate the relative adsorption capacity of the system (Mohan and Singh, 2002).

The results of copper ions adsorption onto clay (Fig. 10) were also analyzed using the Langmuir model to evaluate parameters associated to the adsorption behavior. The linear form of Langmuir equation at a given temperature is represented by Equation 3:

$\frac{C_{e}}{Q}=\frac{1}{Q_{0} b}+\frac{C_{e}}{Q_{0}}$

where, $C e$ is the aqueous phase equilibrium concentration $(\mathrm{mg} / \mathrm{L})$, qe the amount of metal ions adsorbed onto $1 \mathrm{~g}$ of the considered adsorbent, $b$ the adsorption constant $(\mathrm{L} / \mathrm{mg}$ ) related to the energy of adsorption and $Q$ is the maximum adsorption capacity $(\mathrm{mg} / \mathrm{g})$.

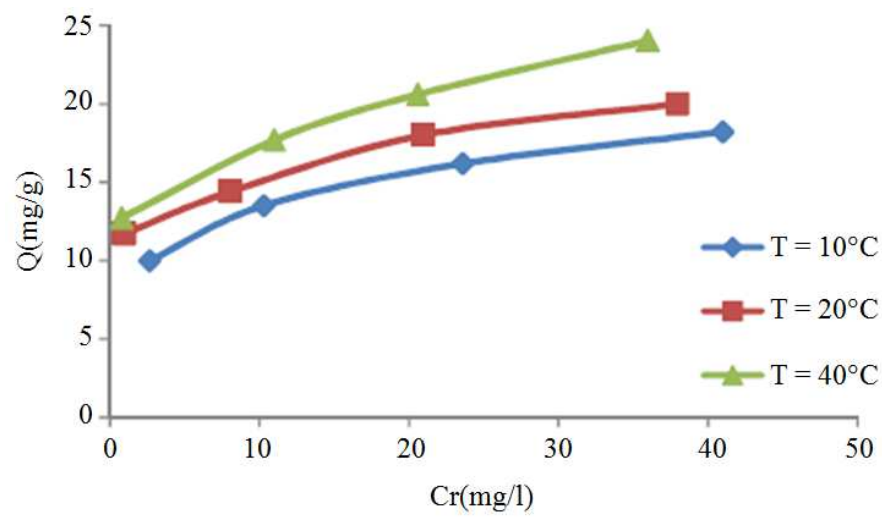

Fig. 8. Equilibrium isotherms for $\mathrm{Cu}(\mathrm{II})$ ions removal by clay $\left(1.5 \mathrm{~g}\right.$ adsorbent $/ 200 \mathrm{~mL}$ effluent, $\mathrm{T}=10,25$ and $\left.40^{\circ} \mathrm{C}, \mathrm{pH} 5\right)$

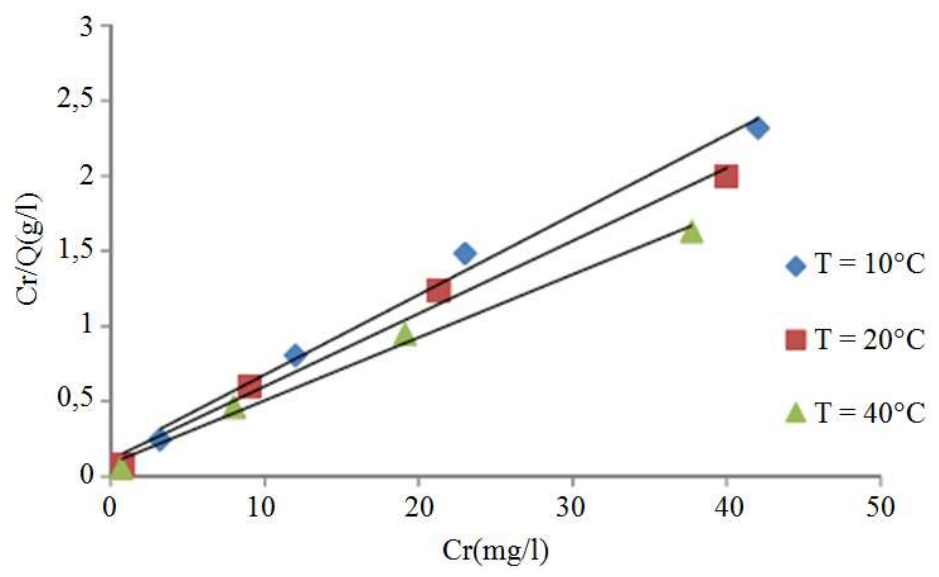

Fig. 9. Freundlich isotherms for the adsorption of $\mathrm{Cu}(\mathrm{II})$ at $\mathrm{T}=10,25$ and $40^{\circ} \mathrm{C}$ on clay 


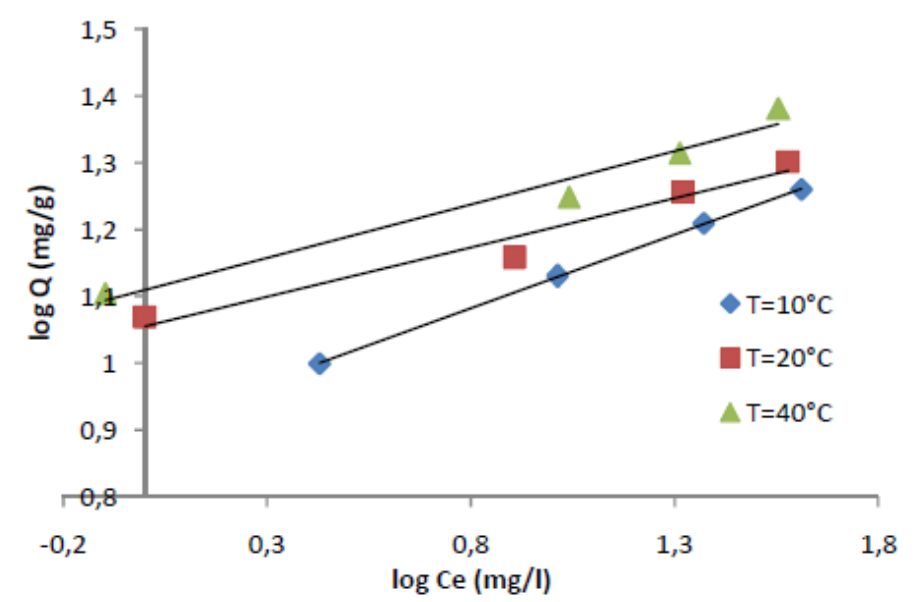

Fig. 10. Langmuir isotherms for the adsorption of $\mathrm{Cu}(\mathrm{II})$ at $\mathrm{T}=10,25$ and $40^{\circ} \mathrm{C}$ on clay

Table 3. Freundlich and Langmuir constants for $\mathrm{Cu}(\mathrm{II})$ adsorption on clay

\begin{tabular}{llll}
\hline Temperature $\left({ }^{\circ} \mathrm{C}\right)$ & $\mathrm{Q}_{0}(\mathrm{mg} / \mathrm{g})$ & $\mathrm{b}(1 / \mathrm{mg})$ & $\mathrm{R}^{2}$ \\
\hline 10 & 19.60 & 0.286 & 0.994 \\
20 & 22.22 & 0.310 & 0.983 \\
40 & 25.02 & 0.353 & 0.978 \\
& $\mathrm{~K}_{\mathrm{f}}$ & $1 / \mathrm{n}$ & $\mathrm{R}^{2}$ \\
10 & 8.83 & 0.191 & 0.911 \\
20 & 11.01 & 0.158 & 0.891 \\
40 & 13.93 & 0.128 & 0.883 \\
\hline
\end{tabular}

Table 4. Thermodynamic parameters for the adsorption of $\mathrm{Cu}$ (II) at various temperatures on clay

\begin{tabular}{llll}
\hline Temperature $\left({ }^{\circ} \mathrm{C}\right)$ & $\Delta \mathrm{H}^{\circ}(\mathrm{KJ} / \mathrm{mol})$ & $\Delta \mathrm{G}^{\circ}(\mathrm{KJ} / \mathrm{mol})$ & $\Delta \mathrm{S}^{\circ}(\mathrm{KJ} / \mathrm{K} . \mathrm{mol})$ \\
\hline 10 & 5.18 & -22.95 & 0.099 \\
20 & 5.18 & -23.94 & 0.099 \\
40 & 5.18 & -25.92 & 0.099 \\
\hline
\end{tabular}

Table $3 \mathrm{a}$ indicates that the Langmuir equation gives a fairly good application for copper adsorption with a regression coefficient, $\mathrm{R}^{2}$ equal to 0.98 . The maximum adsorption capacity at $298^{\circ} \mathrm{K}$ for the metals can be estimated at $22.22 \mathrm{mg} / \mathrm{g}$. This capacity is high compared to other adsorbents (iron oxide coated sand $Q_{0}$ is equal to $5.93 \mathrm{mg} / \mathrm{g}$ (Boujelben, 2011); and phosphate rock, $Q_{0}$ is equal to $11.77 \mathrm{mg} / \mathrm{g}$ (Elouear, 2011)). Thus, notes the effectiveness of the used sorbent.

\section{Adsorption Thermodynamic Parameters}

In order to explain the effect of temperature on the adsorption thermodynamic parameters, standard Gibbs free energy $\left(\Delta G^{\circ}\right)$, standard enthalpy $\left(\Delta H^{\circ}\right)$ and standard entropy $\left(\Delta S^{\circ}\right)$ were determined. The adsorption process of metal ions can be summarized by the following reversible process which represents a heterogeneous equilibrium. The equation (Equation 4) given below was used to determine the Gibbs free energy of adsorption $\left(\Delta G^{\circ}\right)$ (Altin et al., 1999; Mohan and Singh, 2002):
$\Delta G^{\circ}=-R T \ln b$

where, $R$ is the gas constant $8.31410^{-3} \mathrm{~kJ} /(\mathrm{mol} \mathrm{K}), T$ is absolute temperature, $K$ and $b$ are equilibrium constants at temperature $T$, respectively. The other useful relationships are the change in standard enthalpy, $\Delta H^{\circ}$ and standard entropy, $\Delta S^{\circ}$ and they are given by Equation 5:

$\log b=\frac{\Delta S^{\circ}}{2.303 R}-\frac{\Delta H^{\circ}}{2.303 R T}$

When $\ln b$ is plotted against $1 / T$, a straight line with slope $\Delta H / R$ and intercept $\Delta S / R$ is obtained. The values of $\Delta H$ and $\Delta S$ were obtained from the slope and intercept of the Van't Hoff plots of $\ln b$ Vs. $1 / T$.

The thermodynamic parameters for the adsorption process are given in Table 4. The Gibbs free energy indicates the degree of spontaneity of the adsorption process and the higher negative value reflects a more energetically favorable adsorption. 
However, Positive values of $\Delta H$ suggest the endothermic nature of the $\mathrm{Cu}(\mathrm{II})$ adsorption on clay adsorbent. The positive values of $\Delta S$ reflect the affinity of clay for $\mathrm{Cu}$ (II) and show the increasing randomness at the solid/liquid interface during the sorption of metal ions on clay.

\section{Conclusion}

The above results can provide a process for developing a low-cost technology based on adsorption by natural materials for metal ions removal from wastewater. The wide range of experiments performed showed essentially that:

- The mineralogical and chemical analyzes showed that the types of natural material used were illite kaolinite

- The adsorption of copper depended on the solution $\mathrm{pH}$. Maximum retention occurred at around; $\mathrm{pH} 5$, shaking time $60 \mathrm{~min}$, adsorbent amount $1.5 \mathrm{~g} / 200$ $\mathrm{mL}$ and temperature $40^{\circ} \mathrm{C}$

- For the adsorption isotherms of copper ions, both Langmuir and Freundlich equations were fitted to experimental data satisfactorily

- These results led to classify the Tunisian illite kaolinite of the Cap bon region as a new lowcost adsorbent of some well-known adsorbents for wastewater cleanup

\section{Acknowledgment}

This study was carried out in collaboration with the laboratory Eau Energie et Environment and unite de chimie industrielle I. The authors are thankful to Mr. Z. Fakhfakh, for his assistance in electronic microscopy, Madam R. Gargouri Bouzid and Mr. H.F. Ayadi for their collaboration.

\section{Funding Information}

This article was funded by the Ministry of High Education and Scientific Research of Tunisia, under contract program. The funders had no role in study design, data collection and analysis, decision to publish, or preparation of the manuscript.

\section{Author's Contributions}

Nesrine Boujelben: Participated in all experiments, coordinated the data-analysis and contributed to the writing of the manuscript.

Sana Ghrab: Participated in all experiments and coordinated the data-analysis.

Farah Bouhamed: Designed the research plan and organized the study.
Zouheir Elouear and Jalel Bouzid: Coordinated the mouse work.

\section{Ethics}

This article is original and contains unpublished material. The corresponding author confirms that all of other authors have read and approved the manuscript and no ethical issues involved.

\section{References}

Abollino, O., M. Acetob, M. Malandrinoa, C. Sarzaninia and E. Mentasti, 2002. Adsorption of heavy metals on Na-montmorillonite. Effect of $\mathrm{pH}$ and organic substances. Water Res., 37: 1619-1627. DOI: 10.1016/S0043-1354(02)00524-9

Altin, O., O.H. Ozbelge and T. Dogu, 1999. Effect of pH, flow rate and concentration on the sorption of $\mathrm{Pb}$ and $\mathrm{Cd}$ on montmorillonite: I. Experimental. J. Chem. Technol. Biotechnol., 74: 1131-1138. DOI: 10.1002/(SICI)1097-4660(199912)74:12<1131::AIDJCTB158>3.0.CO;2-0

Babel, S. and T.A. Kurniawan, 2003. Low-cost adsorbents for heavy metals uptake from contaminated water: A review. J. Hazard. Mater. B, 97 : 219-243. DOI: $10.1016 / \mathrm{S} 0304-3894(02) 00263-7$

Benzina, M. and A. Bellagi, 1990. Détermination des propriétés du réseau poreux de matériaux argileux par les techniques d'adsorption d'azote et de porosimétrie au mercure en vue de leur utilisation pour la récupération des gaz. Annales de Chimie, 15: 315-335.

Boujelben, N., 2011. Etude des performances des matériaux de filtration recouverts d'oxydes métalliques dans le traitement des eaux. PhD Thèse, L'Ecole Nationale d'Ingénieurs de Sfax.

Camp, R.T., 1964. Water and its Impurities. 2nd Edn., Reinhold, New York.

Dean, J.C., F.L. Bosqui and K.H. Lanovette, 1972. Removing heavy metals from waste water. Environ. Sci. Technol., 6: 509-518. DOI: 10.1021/es60065a006

Das, N. and R.K. Jana, 2005. Adsorption of some bivalent heavy metal ions from aqueous solutions by manganese nodule leached residues. J. Colloid Interface Sci., 293: 254-262. PMID: 16095602

Dhakal, R.P., K.N. Ghimiere and K. Inoue, 2005. Adsorptive separation of heavy metals from an aquatic environment using orange waste. Hydrometallurgy, 79: 182-190.

DOI: 10.1016/j.hydromet.2005.06.007

Elouear, Z., 2011. Etude des potentialités du phosphate tunisien et des cendres dans l'élimination de micropolluants minéraux dans les eaux et les sols. PhD Thèse, L'Ecole Nationale d'Ingénieurs de Sfax. 
Frimmel, F.H. and L. Huber, 1996. Influence of humic substances on the aquatic adsorption of heavy metals on defined mineral phases. Environ. Int., 22: 507-517. DOI: 10.1016/0160-4120(96)00040-2

Gupta, S. and K.G. Bhattacharyya, 2006. Adsorption of Ni(II) on clays. J. Colloid Interface Sci., 295: 21-32. DOI: $10.1016 /$ j.jcis.2005.07.073

Kumar, U. and M. Bandyopadhyay, 2006. Sorption of cadmium from aqueous solution using pretreated rice husk. Bioresour. Technol., 97: 104-109. DOI: 10.1016/j.biortech.2005.02.027

Liang, S., X.Y. Guo, N.C. Feng and Q.H. Tian, 2009. Application of orange peel xanthate for the adsorption of $\mathrm{Pb}^{2+}$ from aqueous solutions. J. Hazard Mater., 170: 425-429.

DOI: 10.1016/j.jhazmat.2009.04.078

Mohan, D. and C.U. Pittman, 2006. Activated carbons and low cost adsorbents for remediation of triand hexavalent chromium from water. J. Hazard. Mater. B, 137: 762-811.

DOI: $10.1016 /$ j.jhazmat.2006.06.060
Mohan, D. and K.P. Singh, 2002. Single- and multicomponent adsorption of cadmium and zinc using activated carbon derived from bagasse-an agricultural waste. Water Res., 36: 2304-2318. DOI: 10.1016/S0043-1354(01)00447-X

Schindler, P.W., F. Urst, B.R. Dick and P.U. Wolf, 1996. Ligand properties of surface silanol groups. I. Surface complex formation with $\mathrm{Fe}^{3+}, \mathrm{Cu}^{2+}, \mathrm{Cd}^{2+}$ and $\mathrm{Pb}^{2+}$. J. Colloid Interface Sci., 55: 469-475. DOI: 10.1016/0021-9797(76)90057-6

Shukla, S.S., L.J. Yua, L.D. Kenneth and S. Alka, 2005. Removal of nickel from aqueous solutions by sawdust. J. Hazard. Mater., 121: 243-246. DOI: $10.1016 /$ j.jhazmat.2004.11.025

Singh, K.K., M. Talat and S.H. Hasan, 2006. Removal of lead from aqueous solutions by agriculture waste maize bran. Bioresour. Technol., 97: 2124-2130. DOI: 10.1016/j.biortech.2005.09.016

Zhang, W., Q.G. Chang, W.D. Liu, B.J. Li and W.X. Jiang et al., 2007. Selecting activated carbon for water and wastewater treatability studies. Environ. Prog., 26: 289-298. DOI: 10.1002/ep.10222 